\title{
Elective laparoscopic deroofing to treat the spontaneous rupture of a large simple liver cyst: a case report
}

Yuki Imaoka, Masahiro Ohira, Tsuyoshi Kobayashi, Seiichi Shimizu, Hiroyuki Tahara, Shintaro Kuroda, Kentaro Ide, Kohei Ishiyama and Hideki Ohdan

\begin{abstract}
Background: The spontaneous rupture of nonparasitic liver cysts (NLC) is sometimes seen in clinical practice. However, there are no guidelines that describe the optimal treatment strategy and the surgical indications for an NLC rupture due to a small number of reports. Here, we present a case who underwent elective laparoscopic deroofing to treat a spontaneously ruptured NLC that had undergone conservative treatment.

Case presentation: A 67-year-old woman was referred to our hospital for the evaluation of acute abdominal pain after the conservative treatment of an NLC at another hospital. She had stable vital signs and no abdominal rigidity. We performed an elective laparoscopic deroofing following an examination of the cyst relative to the bile ducts and the patient's general condition. Computed tomography (CT) and magnetic resonance imaging (MRI) showed that there was no solid mass in the cyst. During the laparoscopic surgery, the cyst wall was resected and the back wall of the cyst was incinerated using an inverse-opal-structure electrode. The patient's postoperative course was stable without any complications.

Conclusions: We succeeded the conservative therapy and the elective laparoscopic surgery for ruptured of NLC. However, elective surgery in spontaneously ruptured NLC with intraabdominal infection or hemorrhage is still challenging.
\end{abstract}

Keywords: Laparoscopy, Liver cyst, Rupture

\section{Background}

Nonparasitic liver cysts (NLCs) are congenital benign malformations that occur in approximately $1-5 \%$ of the general population [1]. NLCs are usually asymptomatic, and they are found more frequently in women than in men at a ratio of 3:1 [1]. When NLCs reach substantial sizes, which occurs in $5 \%$ of the cases, they may become symptomatic and they can be associated with upper abdominal pain, bloating, nausea, vomiting, and dyspnea [2]. NLCs are commonly associated with a variety of complications, including hemorrhages, infections, and ruptures [3, 4]. The spontaneous rupture of NLC is sometimes seen in clinical practice. However, only 18

\footnotetext{
* Correspondence: mohira@hiroshima-u.ac.jp

Department of Gastroenterological and Transplant Surgery, Applied Life Sciences, Institute of Biomedical and Health Sciences, Hiroshima University, 1-2-3 Kasumi, Minami-ku, Hiroshima 734-8551, Japan
}

publications described NLC ruptures. Therefore, there are no guidelines that describe the optimal treatment strategy and the surgical indications for an NLC rupture [4-21]. Here, we describe a rare case of elective laparoscopic deroofing to treat an NLC that ruptured spontaneously after conservative treatment.

\section{Case presentation}

A 67-year-old Japanese woman was transferred to the emergency unit of our hospital for an evaluation of her acute abdominal pain. She had a 2-week history of conservative treatment with antibiotics for an NLC at another hospital (Fig. 1a).

On examination, the patient's pulse rate was 80 beats/ min, her blood pressure was 136/68 $\mathrm{mmHg}$, and she did not have a fever. Her abdomen was flat but painful. The patient did not complain of nausea, vomiting, or diarrhea. 

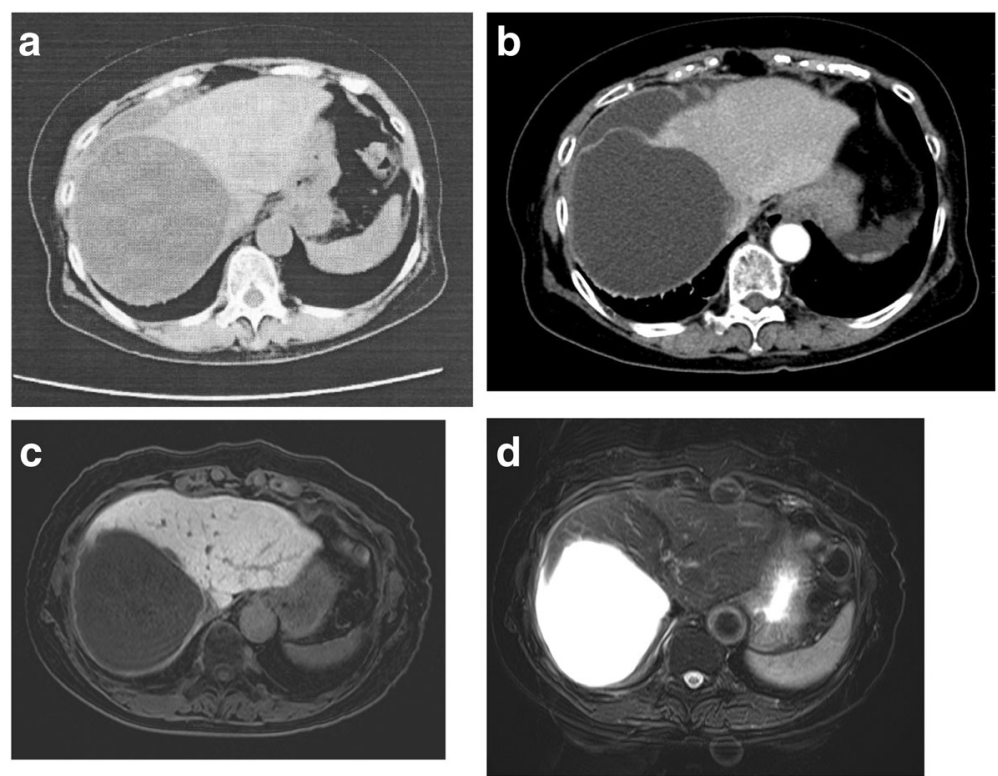

Fig. 1 a Computed tomography (CT) scan before admission to hospital. b CT scan during the examination. c Magnetic resonance imaging (MRI) T1-weighted image. d MRI T2-weighted image

She did not exhibit abdominal tenderness or muscular defense on her arrival at the clinic. The laboratory test results did not reveal liver dysfunction, and the patient's total bilirubin level was $0.8 \mathrm{mg} / \mathrm{dL}$, the prothrombin activity and international normalized ratio were $99 \%$ and 1.01 , respectively, the creatinine level was $0.63 \mathrm{mg} / \mathrm{dL}$, the platelet count was $313,000 / \mu \mathrm{L}$, and the albumin concentration was $3.9 / \mathrm{dL}$. Other blood test results revealed acute inflammation, the absence of anemia, a white blood cell count of 16,350 cells $/ \mu \mathrm{L}$, a hemoglobin level of $13.4 \mathrm{~g} / \mathrm{dL}$, and a C-reactive protein level of $0.57 \mathrm{mg} / \mathrm{dL}$. The levels of carcinoembryonic antigen and carbohydrate antigen 19-9 were within the normal ranges. There were no findings of neoplastic cysts in the abdominal ultrasound test. Enhanced computed tomography (CT) scanning showed a ruptured hepatic cyst without any extravasation, and a moderate amount of ascites fluid around the liver's surface. The largest cyst was $10.5 \mathrm{~cm}$ and it was located on the anterior segment (Fig. 1b). The cyst's volume had clearly declined compared with previous CT images. Magnetic resonance imaging (MRI) showed that the cyst did not contain a solid component (Fig. 1c, d). Based on the patient's clinical course and the findings from the investigations, we determined that the ruptured NLC had not induced acute peritonitis; therefore, the patient received the antibiotics therapy (cefmetazole $3 \mathrm{~g} /$ day) prior to the surgery and was performed an elective laparoscopic deroofing after the patient's general condition was assessed.

A laparoscopic deroofing was performed to rupture the NLC and achieve intraperitoneal drainage. Celioscopy was performed through a point below the umbilicus, and four trocars were necessary for the procedure. The 12-degree optical trocar was installed beneath the umbilicus with the 12-mm operator's trocar in the epigastric region and two 5 - $\mathrm{mm}$ trocars in the right hypochondrium and right subcostal region for apprehension. Harmonic shears (Ethicon US, LLC) and a bipolar cautery coagulation device were required. The cyst was on the right lobe and there were adhesions on the transverse colon, omentum, and peritoneum (Fig. 2a). The cyst was opened and $300 \mathrm{~mL}$ of brown and slightly muddled fluid were aspirated. No obvious hematomas, ascitic fluid, nodules, or other specific entities, for example, a malignant tumor, were detected. The culture of the peritoneal fluid showed no bile and no bacterium. The cyst wall was resected at the junction of the cyst and the liver parenchyma using an ultrasonic scalpel (Fig. 2b). The back wall of the cyst was checked carefully for evidence of a bile leak, and it was incinerated using an inverse-opal-structure electrode while avoiding Glisson's capsule (Fig. 2c). The operation time was $133 \mathrm{~min}$, and the total blood loss was $20 \mathrm{~mL}$.

Pathological investigation revealed no evidence of malignancy and Echinococcus species infection. The patient's postoperative course was stable and there were no complications. She was discharged on postoperative day 6. There have been no recurrences for 8 months.

\section{Conclusions}

We have described a rare case of elective laparoscopic deroofing for the treatment of an NLC that ruptured spontaneously after conservative treatment. Since the rupture did not induce acute peritonitis and the patient's 

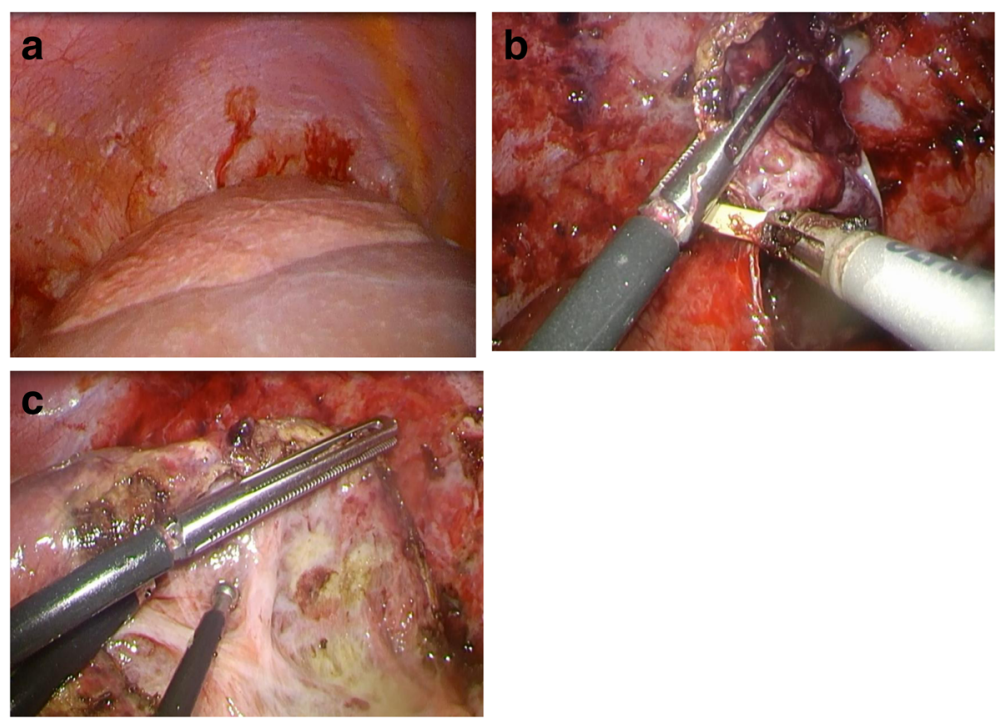

Fig. $\mathbf{2}$ a The cyst on the right lobe. $\mathbf{b}$ The cyst wall was resected at the junction of the cyst. c The back wall of the cyst was incinerated using an inverse-opal-structure electrode while avoiding Glisson's capsule

vital signs were stable, the preoperative examination was carried out while the patient was being treated conservatively with antibiotics. We were able to avoid an emergency operation and to safely perform an elective laparoscopic deroofing without an NLC recurrence.

In general, ruptures of parasitic liver cysts tend to be caused by Echinococcus species, they are known complications associated with these cysts, and they are reported as hydatid cyst ruptures $[5,6]$. On the other hand, a search of English language papers published in PubMed from 1959 to 2015 identified only 18 publications that describe NLC ruptures [4-21] (Table 1), and, of these, only one other case was treated using laparoscopy [14] (Table 2). Seven cases required emergency operations, and one case died postoperatively. Six of seven cases with intracystic bleeding required the emergency surgery. Intracystic bleeding would increase the tension inside the cyst and lead to rupture with shock. The other case has undergone left trisegmentectomy of the liver under a suspected diagnosis of cystadenocarcinoma as elective surgery [19]. Conservative management involving percutaneous drainage and antibiotics might be useful for cases who do not have peritoneal irritation and shock [4]. However, high recurrence rates have been reported after conservative treatment alone [22, 23]. Transcatheter arterial embolization (TAE) was reported as a useful option for spontaneous rupture of the cyst with intracystic bleeding and stable vital sign [17]. Unfortunately, the cyst had increased in size in a short period and required the simple cystectomy. More radical approaches, including cyst resections, atypical resections, and lobectomies, have been undertaken, and the recurrence rates were zero. However, these approaches are often associated with higher morbidity rates [24]. In relation to curability, the risk of relapse, and the possibility of other complications, including hemorrhages, cyst deroofing might be more favorable for most cases [2]. More recently, a laparoscopic approach was proposed and it was considered safe essentially [14, 25]. Increasingly, laparoscopic deroofing is being used in elective operations to manage NLCs that have not ruptured. The findings from a variety of studies have shown that laparoscopic deroofing is associated with reductions in morbidity, shorter hospital stays, and more rapid returns to normal activities, compared with open deroofing [26]. On the other hand, laparoscopic surgery in spontaneously ruptured NLC with intraabdominal infection or hemorrhage is still challenging. The exposure of the cyst may become difficult because the partially collapsed cyst would make the line of resection less obvious on laparoscopic examination [14]. And the active bleeding would make the views worse. In the cases of the intraabdominal infection such as acute peritonitis, the laparotomy surgery with drainage should be selected. Emergency surgery should be avoided, if possible, because they increase postoperative morbidity and mortality [27]. However, we should not hesitate to perform the emergency surgery. The ascites puncture should be the most reliable method to distinguish intraabdominal infection or hemorrhage.

Lai et al. [28] reported that the presence of biliary communication and malignancy could not be accurately determined preoperatively, despite technological advances. We suggest that careful examination of the cyst cavity at 


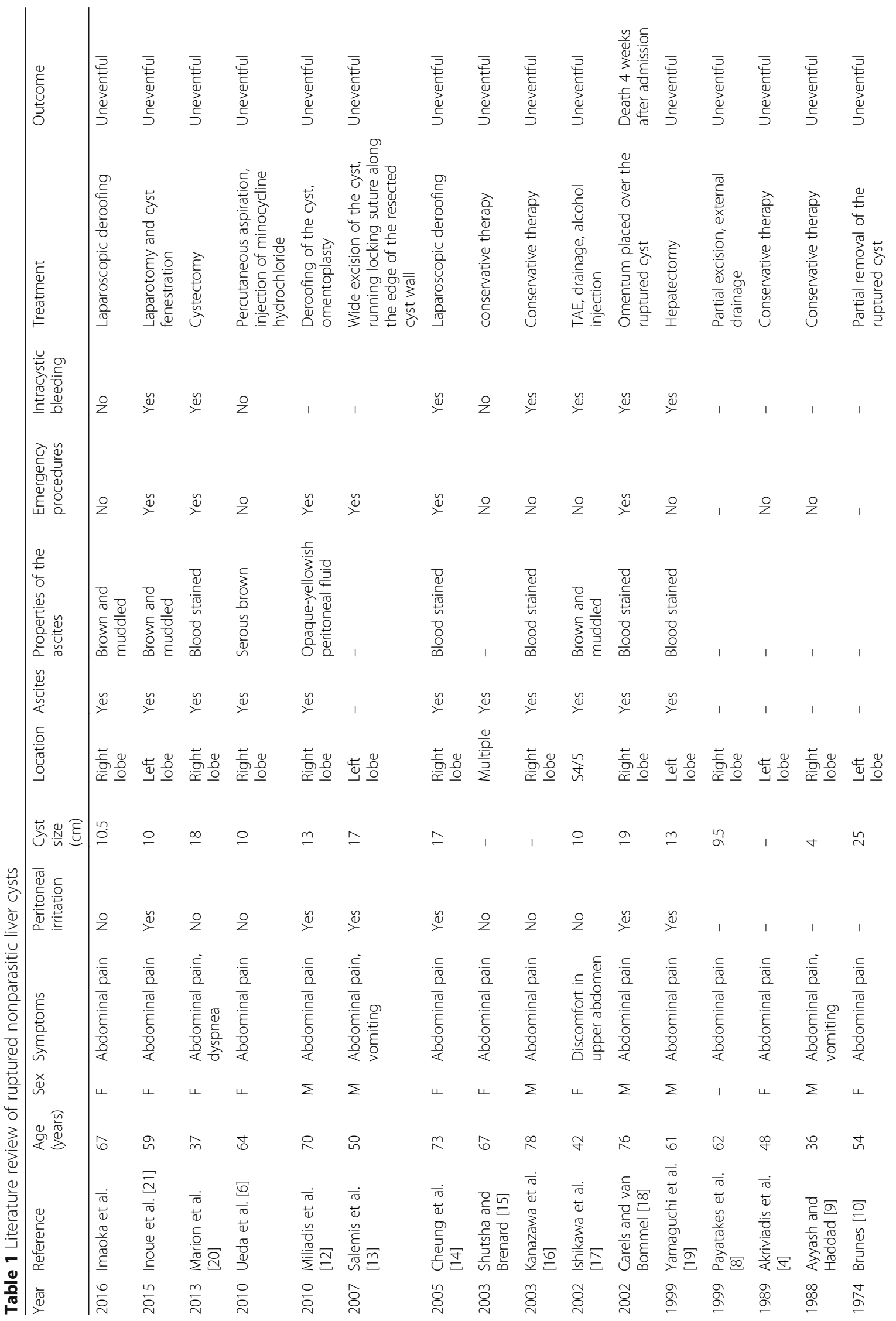




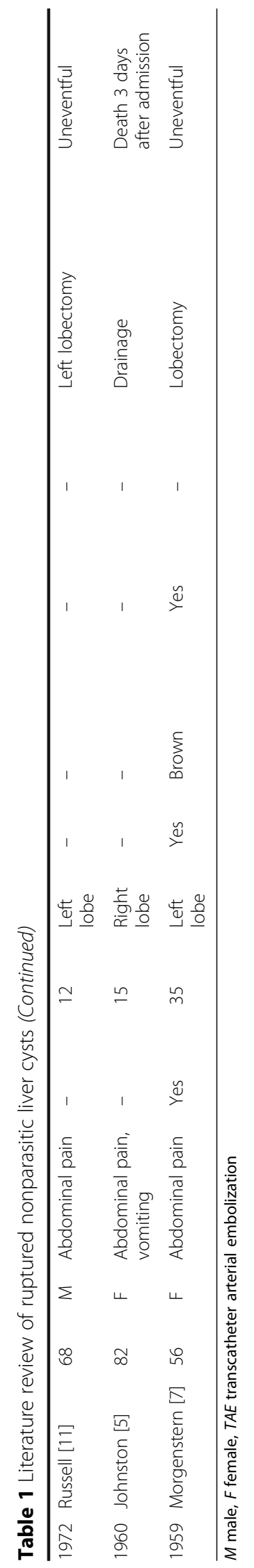


Table 2 Reports describing ruptured nonparasitic liver cysts treated with laparoscopy

\begin{tabular}{|c|c|c|c|c|c|c|c|c|c|c|c|c|c|}
\hline Year & Reference & $\begin{array}{l}\text { Age } \\
\text { (years) }\end{array}$ & Sex & Symptoms & $\begin{array}{l}\text { Peritoneal } \\
\text { irritation }\end{array}$ & $\begin{array}{l}\text { Cyst } \\
\text { size } \\
(\mathrm{cm})\end{array}$ & Location & Ascites & $\begin{array}{l}\text { Properties } \\
\text { of ascites }\end{array}$ & $\begin{array}{l}\text { Emergency } \\
\text { procedures }\end{array}$ & $\begin{array}{l}\text { Intracystic } \\
\text { bleeding }\end{array}$ & Treatment & Outcome \\
\hline 2016 & $\begin{array}{l}\text { Imaoka } \\
\text { et al. }\end{array}$ & 67 & $F$ & $\begin{array}{l}\text { Abdominal } \\
\text { pain }\end{array}$ & No & 10.5 & $\begin{array}{l}\text { Right } \\
\text { lobe }\end{array}$ & Yes & $\begin{array}{l}\text { Brown } \\
\text { and } \\
\text { muddled }\end{array}$ & No & No & $\begin{array}{l}\text { Laparoscopic } \\
\text { deroofing }\end{array}$ & Uneventfu \\
\hline 2005 & $\begin{array}{l}\text { Cheung } \\
\text { et al. [14] }\end{array}$ & 73 & $\mathrm{~F}$ & $\begin{array}{l}\text { Abdominal } \\
\text { pain }\end{array}$ & Yes & 17 & $\begin{array}{l}\text { Right } \\
\text { lobe }\end{array}$ & Yes & $\begin{array}{l}\text { Blood } \\
\text { strained }\end{array}$ & Yes & Yes & $\begin{array}{l}\text { Laparoscopic } \\
\text { deroofing }\end{array}$ & Uneventfu \\
\hline
\end{tabular}

$F$ female

surgery remains the most reliable guide and leads to prevent intraoperative injury of biliary duct. The usefulness of an argon beam coagulation for preventing cyst recurrence was reported in 2003 [29]. We perform the coagulation of the remnant cyst wall as a routine technique. Another risk is the use of argon beam coagulation and electrocoagulation during surgery that could destroy a bile duct that is adjacent to the cyst's wall, leading to postoperative bile leakage. The argon beam coagulator is also known to have a risk to the gas emboli due to increased intraabdominal pressure under laparoscopic condition. Analysis of the literature and experienced surgeons propose its use respecting some rules: avoiding direct application close to the parenchymal surface, no pulverization on small hepatic veins holes, and venting the abdomen (open trocars) in order to decrease the intraperitoneal pressure [30]. Nowadays, PDE camera using
ICG was reported that it is important to detect bile duct and intraoperatively $[31,32]$.

Before this case, we had not treated a ruptured NLC at our hospital. Between 2006 and 2015, we undertook nine nonemergency laparoscopic deroofing for NLCs (Table 3). One case was transferred to undergo laparotomy, and none of the cases experienced complications. There were no differences between the present case and the other nine cases with respect to the operative findings and the postoperative outcomes, despite the current case experiencing a cyst rupture. Five cases had undergone imaging using DIC-CT, MRI, and magnetic resonance cholangiopancreatography (MRCP) to determine the courses that the bile ducts followed. The ascites fluid has a high signal and MRCP cannot provide the precious information in the cases with ascites. Therefore, MRCP was avoided in the present case.

Table 3 Cases with nonparasitic liver cysts treated with laparoscopy

\begin{tabular}{|c|c|c|c|c|c|c|c|c|c|c|c|}
\hline Year & $\begin{array}{l}\text { Age } \\
\text { (years) }\end{array}$ & Sex & Location & Imaging & Treatment & $\begin{array}{l}\text { Operation } \\
\text { time (min) }\end{array}$ & $\begin{array}{l}\text { Blood } \\
\text { loss (mL) }\end{array}$ & $\begin{array}{l}\text { Cyst size } \\
(\mathrm{cm})\end{array}$ & $\begin{array}{l}\text { Drainage } \\
\text { volume }(\mathrm{mL})\end{array}$ & Complications & $\begin{array}{l}\text { Hospital } \\
\text { stay (days) }\end{array}$ \\
\hline 2006 & 80 & $\mathrm{~F}$ & $\begin{array}{l}\text { Right lobe } \\
\text { S5.6 }\end{array}$ & $\mathrm{DIC}-\mathrm{CT}$ & Laparoscopy & 105 & 10 & 9 & - & No & 12 \\
\hline 2006 & 14 & $\mathrm{~F}$ & $\begin{array}{l}\text { Right lobe } \\
\text { S7 }\end{array}$ & - & Laparoscopy & 155 & 20 & 18 & - & No & 5 \\
\hline 2008 & 39 & $\mathrm{~F}$ & $\begin{array}{l}\text { Right lobe } \\
\text { S6 }\end{array}$ & - & Laparoscopy & 106 & 10 & 16 & 2800 & No & 10 \\
\hline 2010 & 63 & $\mathrm{~F}$ & $\begin{array}{l}\text { Multiple } \\
\text { S2.3.7, S6 }\end{array}$ & MRI & $\begin{array}{l}\text { Laparoscopy } \rightarrow \\
\text { laparotomy }\end{array}$ & 198 & 50 & 10 & - & No & 8 \\
\hline 2010 & 77 & $\mathrm{~F}$ & $\begin{array}{l}\text { Right lobe } \\
\text { S7 }\end{array}$ & - & Laparoscopy & 135 & 20 & 18 & 3000 & No & 7 \\
\hline 2011 & 66 & $\mathrm{~F}$ & $\begin{array}{l}\text { Right lobe } \\
\text { S5 }\end{array}$ & - & Laparoscopy & 129 & 10 & 12 & - & No & 4 \\
\hline 2012 & 81 & $\mathrm{~F}$ & $\begin{array}{l}\text { Multiple } \\
\text { S8 S2 }\end{array}$ & $\begin{array}{l}\text { DIC-CT } \\
\text { MRI }\end{array}$ & Laparoscopy & 160 & 30 & 12 & - & No & 19 \\
\hline 2013 & 78 & $\mathrm{~F}$ & $\begin{array}{l}\text { Right lobe } \\
\text { S6 }\end{array}$ & MRCP & Laparoscopy & 149 & 10 & 21 & 2800 & No & 6 \\
\hline 2013 & 74 & M & $\begin{array}{l}\text { Right lobe } \\
\text { S6 }\end{array}$ & $\begin{array}{l}\text { DIC-CT } \\
\text { MRCP }\end{array}$ & Laparoscopy & 226 & 190 & 24 & 5000 & No & 8 \\
\hline Average & 63.6 & & & & & 151 & 39 & 16 & 3400 & 0/9 & 9 \\
\hline 2016 & 67 & $\mathrm{~F}$ & Right lobe & MRI & Laparoscopy & 133 & 20 & 10.5 & 300 & No & 6 \\
\hline
\end{tabular}

$F$ female, $M$ male, DIC-CT drip infusion cholangiography computed tomography, $M R I$ magnetic resonance imaging, $M R C P$ magnetic resonance cholangiopancreatography 
In conclusion, we succeeded the conservative therapy and the elective laparoscopic surgery for ruptured NLC. We suggest that the elective laparoscopic surgery is just one option, but is useful for the stable patients. However, elective surgery in spontaneously ruptured NLC with intraabdominal infection or hemorrhage is still challenging.

\section{Abbreviations}

CT: Computed tomography; DIC-CT: Drip infusion cholangiography computed tomography; MRCP: Magnetic resonance cholangiopancreatography; MRI: Magnetic resonance imaging;

NLCs: Nonparasitic liver cysts; TAE: Transcatheter arterial embolization

\section{Funding}

The authors declare that this study was not funded externally.

\section{Authors' contributions}

$\mathrm{Yl}$ and $\mathrm{MO}$ performed the investigation, analyzed the data, and wrote the manuscript. SK, $\mathrm{HT}, \mathrm{Kl}, \mathrm{Kl}$, and TK performed the investigation and analyzed the data. $\mathrm{HO}$ designed the study. All authors read and approved the final manuscript.

\section{Competing interests}

The authors declare that they have no competing interests.

\section{Consent for publication}

Consent was obtained from the patient for the publication of this case report.

Received: 20 September 2016 Accepted: 3 December 2016

Published online: 07 December 2016

\section{Reference}

1. Regev A, Reddy KR, Berho M, Sleeman D, Levi JU, Livingstone AS, et al. Large cystic lesions of the liver in adults: a 15-year experience in a tertiary center. J Am Coll Surg. 2001;193:36-45.

2. Ammori BJ, Jenkins BL, Lim PC, Prasad KR, Pollard SG, Lodge JP. Surgical strategy for cystic diseases of the liver in a western hepatobiliary center. World J Surg. 2002;26:462-9.

3. Poggi G, Gatti C, Delmonte A, Teragni C, Bernardo G. Spontaneous rupture of non-parasitic hepatic cyst. Int J Clin Pract. 2006;60:99-103.

4. Akriviadis EA, Steindel H, Ralls P, Redeker AG. Spontaneous rupture of nonparasitic cyst of the liver. Gastroenterology. 1989;97:213-5.

5. Johnston J. Solitary nonparasitic cyst of the liver with rupture. Harper Hosp Bull. 1959;18:318-20.

6. Ueda J, Yoshida H, Taniai N, Mineta S, Kawano Y, Uchida E. A case of spontaneous rupture of a simple hepatic cyst. J Nippon Med Sch. 2010;77:181-5.

7. Morgenstern L. Rupture of solitary nonparasitic cysts of the liver. Ann Surg. 1959;150:167-71.

8. Payatakes AH. Surgical treatment of non-parasitic hepatic cysts: report of 12 cases. Eur J Surg. 1999;165:1154-8.

9. Ayyash $\mathrm{K}$, Haddad J. Spontaneous rupture of a solitary nonparasitic cyst of the liver. Case report Acta Chir Scand. 1988;154:241-3.

10. Brunes L. Rupture of a solitary nonparasitic cyst of the liver. Report of a case. Acta Chir Scand. 1974:140:159-60.

11. Russell RC. Ruptured solitary cyst of the liver. Br I Surg. 1972;59:919-20.

12. Miliadis L, Giannakopoulos T, Boutsikos G, Terzis I, Kyriazanos ID. Spontaneous rupture of a large non-parasitic liver cyst: a case report. J Med Case Rep. 2010:4:2

13. Salemis NS, Georgoulis E, Gourgiotis S, Tsohataridis E. Spontaneous rupture of a giant non parasitic hepatic cyst presenting as an acute surgical abdomen. Ann Hepatol. 2007;6:190-3.

14. Cheung FK, Lee KF, John W, Lai PB. Emergency laparoscopic unroofing of a ruptured hepatic cyst. JSLS. 2005:9:497-9.

15. Shutsha E, Brenard R. Hepatic cyst rupture after a coughing fit. J Hepatol. 2003:38:870

16. Kanazawa A, Yoshioka Y, Inoi O, Kubo S, Kinoshita H. Intracystic hemorrhage with spontaneous rupture of liver cyst complicated by infection: a case report. Osaka City Med J. 2003:49:57-60.
17. Ishikawa H, Uchida S, Yokokura Y, Iwasaki Y, Horiuchi H, Hiraki M, et al. Nonparasitic solitary huge liver cysts causing intracystic hemorrhage or obstructive jaundice. J Hepatobiliary Pancreat Surg. 2002;9:764-8.

18. Carels RA, van Bommel EF. Ruptured giant liver cyst: a rare cause of acute abdomen in a haemodialysis patient with autosomal dominant polycystic kidney disease. Neth J Med. 2002;60:363-5.

19. Yamaguchi M, Kuzume M, Matsumoto T, Matsumiya A, Nakano H, Kumada K. Spontaneous rupture of a nonparasitic liver cyst complicated by intracystic hemorrhage. J Gastroenterol. 1999;34:645-8.

20. Marion Y, Brevartt C, Plard L, Chiche L. Hemorrhagic liver cyst rupture: an unusual life-threatening complication of hepatic cyst and literature review. Ann Hepatol. 2013;12:336-9.

21. Inoue K, Iguchi T, Ito S, Ohga T, Nozoe T, Shirabe K, et al. Rerupture of nonparasitic liver cyst treated with cyst fenestration: a case report. Surg Case Rep. 2015:1:71.

22. Saini S, Mueller PR, Ferrucci Jr JT, Simeone JF, Wittenberg J, Butch RJ. Percutaneous aspiration of hepatic cysts does not provide definitive therapy. AJR Am J Roentgenol. 1983;141:559-60.

23. Tocchi A, Mazzoni G, Costa G, Cassini D, Bettelli E, Agostini N, et al. Symptomatic nonparasitic hepatic cysts: options for and results of surgical management. Arch Surg. 2002;137:154-8.

24. Martin IJ, McKinley AJ, Currie EJ, Holmes P, Garden OJ. Tailoring the management of nonparasitic liver cysts. Ann Surg. 1998;228:167-72.

25. Gigot JF, Hubert C, Banice R, Kendrick ML. Laparoscopic management of benign liver diseases: where are we? HPB (Oxford). 2004;6:197-212.

26. Tan YM, Chung A, Mack P, Chow P, Khin LW, Ooi LL. Role of fenestration and resection for symptomatic solitary liver cysts. ANZ J Surg. 2005;75:577-80.

27. Turrentine FE, Wang H, Simpson VB, Jones RS. Surgical risk factors, morbidity, and mortality in elderly patients. J Am Coll Surg. 2006;203:865-77.

28. Lai EC, Wong J. Symptomatic nonparasitic cysts of the liver. World J Surg. 1990:14:452-6.

29. Kwon AH, Matsui $Y$, Inui H, Imamura A, Kamiyama $Y$. Laparoscopic treatment using an argon beam coagulator for nonparasitic liver cysts. Am J Surg. 2013;185:273-7.

30. Ikegami T, Shimada M, Imura S, Nakamura T, Kawahito S, Morine Y, et al. Argon gas embolism in the application of laparoscopic microwave coagulation therapy. J Hepatobiliary Pancreat Surg. 2009:16:394-8.

31. Ishizawa T, Tamura S, Masuda K, Aoki T, Hasegawa K, Imamura H, et al. Intraoperative fluorescent cholangiography using indocyanine green: a biliary roadmap for safe surgery. J Am Coll Surg. 2009;208:1-4.

32. Mitsuhashi N, Kimura F, Shimizu H, Imamaki M, Yoshidome $H$, Ohtsuka M, et al. Usefulness of intraoperative fluorescence imaging to evaluate local anatomy in hepatobiliary surgery. J Hepatobiliary Pancreat Surg. 2008;15:508-14.

\section{Submit your manuscript to a SpringerOpen ${ }^{\circ}$ journal and benefit from:}

- Convenient online submission

- Rigorous peer review

- Immediate publication on acceptance

- Open access: articles freely available online

- High visibility within the field

- Retaining the copyright to your article

Submit your next manuscript at $>$ springeropen.com 